\title{
Four-Dimensionalism, Evil, and Christian Belief
}

\author{
R. T. Mullins \\ School of Divinity \\ University of Saint Andrews \\ Saint Andrews, Scotland
}

Four-dimensionalism and eternalism are theories on time, change, and persistence. Contemporary Christian philosophers and theologians have adopted four-dimensionalism and eternalism for various reasons. Many find it to be derived from certain interpretations of the special theory of relativity. Others hold it because it is said to comport well with truth-maker theory. In recent literature one can find Christians adopting four-dimensionalism and eternalism for explicitly theological reasons as well as using it to explicate Christian doctrine. For instance, Katherin Rogers and T. J. Mawson have used it to defend divine omniscience and timelessness, Oliver Crisp has used it to articulate the doctrine of atonement, and Michael Rea has deployed it to make sense of original sin. ${ }^{1}$ It would seem, then, that four-dimensional eternalism is a fruitful metaphysical doctrine. But should Christians be four-dimensional eternalists? There appear to be various areas of Christian thought that conflict with four-dimensional eternalism, and these conflicts have not been fully considered.

ABSTRACT: Four-dimensionalism and eternalism are theories on time, change, and persistence. Christian philosophers and theologians have adopted four-dimensional eternalism for various reasons. In this paper I shall attempt to argue that four-dimensional eternalism conflicts with Christian thought. Section I will lay out two varieties of four-dimensionalism-perdurantism and stage theory - along with the typically associated ontologies of time of eternalism and growing block. I shall contrast this with presentism and endurantism. Section II will look at some of the purported theological benefits of adopting four-dimensionalism and eternalism. Section III will examine arguments against four-dimensional eternalism from the problem of evil. Section IV will argue that four-dimensional eternalism causes problems for Christian eschatology.

1. See T. J. Mawson, "Divine Eternity," International Journal for the Philosophy of Religion 64 (2008): xxx-xxx; Katherin Rogers, "Anselmian Eternalism: The Presence of a Timeless God," Faith and Philosophy 24 (2007): xxx-xxx; Oliver Crisp, "Non-Penal Substitution," International Journal of Systematic Theology 9 (2007): xxx-xxx. Also, Crisp, "Original Sin and Atonement," in Oxford Handbook of Philosophical Theology, ed. Thomas Flint and Michael Rea (New York: Oxford University Press, 2009). Michael Rea, "The Metaphysics of Original Sin," in Persons: Human and Divine, ed. Peter van Inwagen and Dean Zimmerman (New York: Oxford University Press, 2007). 
In order to answer this question, several things are called for. Section I of this paper will lay out two varieties of four-dimensionalism - perdurantism and stage theory - along with its typically associated ontologies of timeeternalism and growing block. I shall contrast this with presentism and endurantism. Section II will explicate some of the purported theological benefits of adopting four-dimensionalism and eternalism. Sections III and IV will examine the problems that arise when four-dimensional eternalism is combined with Christian belief. Specifically, four-dimensional eternalism exaggerates the problem of evil and causes problems for eschatology. As such, Christians ought not to be four-dimensional eternalists.

\section{The Ontology of Time and Persistence through Time}

Presentism, the growing block, and eternalism are theories about the ontology of time, or about what moments of time exist. Each is typically linked with a theory of change and persistence through time. Presentism is usually held alongside endurantism, whereas the growing block and eternalism typically hold some version of four-dimensionalism. Allow me to elaborate.

Presentism is the thesis that only the present, the now, exists. The past no longer exists and the future does not yet exist. ${ }^{2}$ Time involves temporal becoming, or absolute generation, as well as real passage from one moment to the next. New things that did not formerly exist come into existence, and other things pass out of existence or cease to exist. ${ }^{3}$ For the presentist, it simply is the case that the only objects that exist are the ones that presently exist. As Trenton Merricks says of presentism, "an object has only those properties it has at the present time. The difference between past, present, and future is metaphysical, not perspectival." ${ }^{\prime 4}$

On presentism, an object endures through time. To say that an object endures through time is to say that an object is wholly present at each moment of its existence. Numerically one and the same object exists at each time that it exists, and it does not have parts at other times. On presentism and endurantism, objects undergo change by gaining and losing accidental properties over time. Let us say that some object $O$ begins to exist at time $t_{1}$ and persists all the way through to time $t_{3}$. On this account $O$ exists entirely at each instant of time. Given presentism, as $t_{2}$ comes into existence $t_{1}$ ceases to exist and $t_{3}$ does not yet exist. So $O$ exists entirely at each instant only

2. Thomas M. Crisp, "Presentism," in The Oxford Handbook of Metaphysics, ed. Michael J. Loux and Dean W. Zimmerman (New York: Oxford University Press, 2003), 212.

3. St. Augustine, Confessions, 9.20; Anselm, Monologion, 21, 22, and 24. Also, Proslogion, 13,19 , and 22 .

4. Trenton Merricks, "Goodbye Growing Block," in Oxford Studies in Metaphysics, vol. 2, ed. Dean W. Zimmerman (New York: Oxford University Press, 2006), 103. 
when that instant is the present. It is not as if $\mathrm{O}$ exists wholly at all of the instants of $t_{1}$ through $t_{3}$ simultaneously because all of those instances do not have equal ontological existence. As $\mathrm{O}$ endures through time it will gain and lose various accidental, or nonessential, properties. Let us say that $\mathrm{O}$ is an armchair. At $t_{1}$ the armchair is blue, and then at $t_{2}$ someone paints the armchair such that at $t_{3}$ the armchair is red. The armchair has retained all of its essential properties, but it has lost one accidental property - that of being blue - and gained a new accidental property - that of being red.

The growing block and eternalism both have the same basic feature of seeing time as a four-dimensional spacetime manifold, but differ in certain respects. ${ }^{5}$ On eternalism, all moments of time have equal ontological existence. To put it roughly the past, present, and the future all exist - they are all equally real. To put it more technically there is no real distinction between past, present, and future. There just is the four-dimensional spacetime manifold with no privileged moment that marks the present. ${ }^{6}$ On this account there is no real passage of time because all moments of time exist. Nothing ever comes into existence nor ceases to exist because everything simply does exist in the spacetime manifold. As such, the experience of temporal passage is illusory. Growing block theorists agree that spacetime is a fourdimensional manifold, but they maintain that only the past and the present exist whereas the future does not. Time is dynamic in the sense that new things really do come into existence as new time slices are added to the fourdimensional spacetime manifold.

Time slices are merely instants of time that can stand in earlier than and later than relations to other instants. They are much like points on a map. In fact most eternalists and growing blockers see a close connection between being located in space and being located at a time, whereas presentists reject the similarity between being located in space and located at a time. ${ }^{7}$ For the growing block theorist new time slices are constantly being added to spacetime. The eternalist holds that all time slices simply exist in the spacetime manifold. None ever come into nor pass out of existence.

Presentists hold that objects endure through time. Growing block theorists and eternalists hold that objects are four-dimensional in that they persist through time by having temporal parts. Four-dimensionalism is a family of views about the nature of temporal parts, and it comes in two basic forms-perdurantism and stage theory. According to Michael Rea

5. Michael Rea, "Four-Dimensionalism," in The Oxford Handbook of Metaphysics, ed. Michael J. Loux and Dean W. Zimmerman (New York: Oxford University Press, 2003$), 247$.

6. J. J. C. Smart, "The Tenseless Theory of Time," in Contemporary Debates in Metaphysics, ed. Theodore Sider, John Hawthorne, and Dean W. Zimmer (Malden: Blackwell Publishing, 2008), 227.

7. Trenton Merricks, Truth and Ontology (New York: Oxford University Press, 2007), 1215. Also, Theodore Sider, "Four-Dimensionalism," Philosophical Review 106 (1997): 197 and 204. 
endurantists hold that objects "last over time by being wholly present at every moment at which they exist," whereas perdurantists hold that objects "last over time without being wholly present at every moment at which they exist." As Sally Haslanger explains, "On the perdurantist's conception of persistence, an object persists through time in a way analogous to how an object is extended through space." The perdurantist sees an object as being spread out across the four-dimensional spacetime manifold by having temporal parts. Each temporal part exists at a particular point in spacetime and together they constitute the object. The object does not exist as a whole throughout time, but instead temporal parts of the object exist at different times. On presentism and endurantism there simply is no such thing as temporal parts.

To complicate matters a bit, perdurantism has various similarities to stage theory. Both involve an object having temporal parts at times, and both explain change in terms of different temporal parts having different properties at different times. ${ }^{10}$ In order to understand the difference between the two, it is helpful to note that perdurantism is sometimes called worm theory. On worm theory objects "stretch out through time just as (we all agree) earthworms stretch out through space." ${ }^{\prime 11}$ When referring to a perdurant object we speak of the entire spacetime worm. On stage theory "the world is full of four-dimensional objects with temporal parts, but when we talk about ordinary objects like boats and people, we talk about brief temporal parts or 'stages' of four-dimensional objects." 12 Perhaps an illustration will help.

Imagine that we ask Tony Bennett to sing "I Left My Heart in San Francisco." The endurantist would say that Tony Bennett is entirely present throughout the 2 minutes and 46 seconds of his performance. There is numerically only one thing, Tony Bennett, which endures through the song. The perdurantist would see things differently. For each second of the song there is a temporal part of Tony Bennett. According to the worm theorist, when you put all of the temporal parts together you get Tony Bennett. Tony is not identical to any of the temporal parts, but somehow through the right causal connections and a particular kind of psychological continuity, the temporal parts together constitute the spacetime worm that is Tony. (In calling Tony a worm this is not to say anything of his moral character. I'm sure he is a standup gentleman.) The stage theorist will say that each temporal part is a Tony Bennett. There is the Tony Bennett that exists at $t_{1}$ and the

8. Michael Rea, "Four-Dimensionalism," in The Oxford Handbook of Metaphysics, ed. Michael J. Loux and Dean W. Zimmerman (New York: Oxford University Press, 2003$), 247$.

9. Sally Haslanger, "Persistence through Time," in The Oxford Handbook of Metaphysics, 318.

10. Katherine Hawley, How Things Persist (Oxford: Oxford University Press, 2001), 11-12.

11. Katherine Hawley, "Temporal Parts," in Stanford Encyclopedia of Philosophy, ed. Edward Zalta, http://plato.stanford.edu/entries/temporal-parts/.

12. Hawley, "Temporal Parts." 
Tony Bennett that exists at $t_{2}$. Worm theory and stage theory have the same underlying four-dimensionalist ontology of temporal parts. The difference between the two is over where the proper name goes. The worm theorist holds that the proper name applies to the spacetime worm, whereas the stage theorist says the proper name applies to each temporal counterpart or stage.

It is sometimes held that endurantism could be compatible with the growing block or eternalism. Yet many think that a problem arises from intrinsic properties and change if endurantism is combined with either of these ontologies of time. ${ }^{13}$ This is because the same object would have contradictory intrinsic properties. Say eternalism is true, and that every moment of "I Left My Heart in San Francisco" is on the same ontological par. If Tony were an endurant being, he would exist as a whole at every moment of the song. As such he would have both of the properties of signing "I left my heart" at time $t_{1}$ and "on a hill it calls to me" at $t_{3}$. He would have the properties "standing" at $\mathrm{t}_{2}$ and "sitting at the piano" at $\mathrm{t}_{4}$. How can Tony be sitting and standing? Aren't these contradictory intrinsic properties? Since Tony exists as a whole at each moment of the song, and since each moment of the song is equally real, all of the properties are within Tony's domain of discourse.

How do we remove the contradiction? The standard move for the eternalist is to adopt a four-dimensionalist thesis of temporal parts. Tony Bennett does not have the contradictory properties. Instead, only the temporal part of Tony that exists at $t_{2}$ has the property "standing" and only the temporal part that exists at $\mathrm{t}_{4}$ has the property "sitting at the piano." The endurantist can remove the contradiction by adopting presentism. On this scheme, Tony had the property "standing" but that moment no longer exists, so Tony no longer has that property. He only exemplifies the properties that exist at the present moment.

With these distinctions laid out before us, we can begin to delve deeper into issues related to four-dimensionalism that have not been fully acknowledged by Christian thinkers who wish to use this metaphysical thesis in Christian doctrine. Four-dimensionalism is often held to come with certain metaphysical commitments that a presentist and endurantist would most likely not accept. One such commitment is metaphysical universalism. The metaphysical doctrine of "[u]niversalism is the view that any collection of objects whatsoever has a sum, an object they compose." This is sometimes called unrestricted mereology. "Any combination of temporal parts of any objects from any times, no matter how scattered and disparate, composes

13. See Thomas M. Crisp, "Presentism," in The Oxford Handbook of Metaphysics, 220. Theodore Sider, Four-Dimensionalism (Oxford: Oxford University Press, 2001), chap. 4. Also, Katherine Hawley, "Why Temporary Properties Are Not Relations between Physical Objects and Times," Proceedings of the Aristotelian Society 98 (1998): 211-16. 
an object." ${ }^{14}$ It could be possible for a four-dimensionalist to reject this metaphysical doctrine, though that will depend on other metaphysical and theological commitments she holds. For instance, she might adopt metaphysical universalism because she takes objects like bicycles and persons to be mere conventions. ${ }^{15}$ Or she could hold to universalism in order to argue that Christ's atonement involves fallen human persons becoming part of a larger four-dimensional object with Christ. ${ }^{16}$ How this is possible without Christ having sinful parts is beyond me, but I digress.

Another metaphysical commitment that four-dimensionalists typically hold, and that presentists typically reject, is Humean supervenience. Katherine Hawley describes this as the view that "facts about which intrinsic properties are instantiated at which points determine all the facts there are. There are no irreducibly holistic facts. In conjunction with perdurantism, this entails that all the facts about a given persisting object supervene upon intrinsic facts about its briefest temporal parts." ${ }^{17}$ Again, a four-dimensionalist may reject this depending on her other metaphysical and theological commitments. What Christian thinkers must do, however, is make it clear which aspects of four-dimensionalism they wish to accept or reject if they wish to use fourdimensionalism in the defense and development of Christian doctrine.

With these metaphysical distinctions in mind we can now turn to the main question of this paper. Should Christians be four-dimensionalists? I shall argue that Christians should not be four-dimensionalists since adopting four-dimensionalism exaggerates the problem of evil and wreaks havoc on eschatology. But in order for the reader to make an informed opinion, it will be helpful to see some of the alleged theological benefits to adopting fourdimensionalism and eternalism. As such, I shall address those issues first.

\section{Reaping the Theological Benefits of Four-Dimensionalism and Eternalism}

As noted above, various Christian philosophers have employed fourdimensionalism and eternalism to develop theological doctrines. Several of these proposals seem underdeveloped or undesirable at the moment, but

14. Katherine Hawley, "Temporal Parts." See also Sider, Four-Dimensionalism, 7. Hud Hudson, The Metaphysics of Hyperspace (Oxford: Oxford University Press, 2005), 5-9.

15. Hawley, "Temporal Parts." Also Mark Heller, "Temporal Parts of Four-Dimensional Objects," in Metaphysics: Contemporary Readings, ed. Michael J. Loux (London: Routledge, 2001), 343-8.

16. Though Oliver Crisp does not explicitly endorse metaphysical universalism, it seems to me that is what is needed in order to make sense of his doctrine of the atonement. See his "Non-Penal Substitution" and "Original Sin and Atonement." It might even be the case that he only needs an unrestricted mereology for his doctrine of atonement, and can do away with four-dimensionalism.

17. Hawley, "Temporal Parts." 
one area has received enough attention and development to be worthy of comment. ${ }^{18}$ In the current debates over God's relationship to time, it is widely agreed that God cannot be timeless if presentism is true, but that God can be timeless if four-dimensional eternalism is true. ${ }^{19}$ One standard move amongst divine temporalists is to argue that four-dimensional eternalism is false, so divine timelessness is false. ${ }^{20}$ Philosophers like Paul Helm, T. J. Mawson, and Katherin Rogers have attempted to defend four-dimensional eternalism and develop its theological benefits. As a divine temporalist, I do not see these as theological benefits. ${ }^{21}$ Yet, atemporalists do see divine timelessness as a benefit. As such, it is these purported benefits for atemporalists that I will focus on in this section.

In order to understand these alleged theological benefits one must have a working definition of divine timelessness. The traditional understanding of divine timelessness is that God exists (a) without beginning, (b) without end, $(c)$ without succession, and $(d)$ without temporal location or extension. Traditionally this has been explained in terms of presentism and endurantism. One of the most popular ways classical Christian theologians articulated divine timelessness was to say that God exists as a whole, all at once, in an eternal present that lacks a before and after. It is $(c)-(d)$ that the temporalist denies, and what the atemporalist seeks to defend by adopting four-dimensional eternalism.

The first purported theological benefit of adopting four-dimensional eternalism is that it avoids the common objection to divine timelessness from creation ex nihilo. Classical theologians held to presentism and divine timelessness. ${ }^{22}$ A common theological prolegomena throughout Church

18. As noted above, four-dimensionalism has been used to flesh out original sin and atonement. Oliver Crisp has begun to develop a doctrine of penal substitionary atonement, but it is somewhat underdeveloped at this time. However, the main objections to penal substitution are moral and biblical. Four-dimensionalism is of no help in defending this doctrine from these objections, so its fruitfulness for the atonement is limited. See Mark C. Murphy, "Not Penal Substitution But Vicarious Punishment," in Faith and Philosophy 26 (2009): xxx-xxx; and Gerald O'Collins, Jesus Our Redeemer: A Christian Approach to Salvation (Oxford: Oxford University Press, 2007).

19. For instance see Kathrin Rogers and William Hasker, "Anselm and the Classical Idea of God: A Debate," in Philosophy of Religion: Key Thinkers, ed. Jeffrey J. Jordan (London: Continuum, 2011).

20. Alan G. Padgett, God, Eternity, and the Nature of Time (Eugene: Wipf \& Stock, 1992). William Lane Craig, Time and Eternity: Exploring God's Relationship to Time (Wheaton: Crossway Books, 2001). Garrett J. DeWeese, God and the Nature of Time (Burlington: Ashgate, 2004).

21. For more on this see my "Divine Perfection and Creation," The Heythrop Journal (forthcoming), and In Search of a Timeless God (forthcoming).

22. See Robert Pasnau, "On Existing All at Once," in God, Eternity, and Time, ed. Christian Tapp and Edmund Runggaldier (Surrey: Ashgate, 2011). Also, Anselm, Proslogion, 13 and 22; Gregory of Nyssa, Against Eunomius, 1.42; Augustine, City of God, 11.21; and Confessions, 11. For a discussion of Augustine's puzzles over the present see Richard Sorabji, Time, Creation and the Continuum: Theories in Antiqity and the Early Middle Ages (London: Duckworth, 
history has centered on divine timelessness and creation ex nihilo. Classical theologians, following various biblical claims, held that there was a state of affairs where God existed alone without creation, and a state of affairs where God exists with creation. Creation is not coeternal with God, because nothing can be coeternal with God. But a problem quickly arises for divine timelessness. If there is a state of affairs where God exists without creation and another where God exists with creation, God has a before and after in His life. Theologians and philosophers like Augustine, John Philoponus, Peter Lombard, Thomas Aquinas, and Bonaventure have attempted to deal with this problem whilst assuming presentism. Helm and Rogers avoid this problem altogether by making the four-dimensional world coeternal with God. ${ }^{23}$ There is no state of affairs where God exists without creation, so no worry of a before and after in His life. Elsewhere I have argued that this does not preserve an adequate understanding of the doctrine of creation ex nihilo, but I will set that issue aside. ${ }^{24}$

A second purported theological benefit is that by adopting fourdimensional eternalism one avoids the problem of divine sustaining for divine timelessness. Christians are committed to the claim that God is sustaining the world as it unfolds through time. On presentism God sustains a moment, then ceases to sustain it, and then sustains another. God would constantly be doing something different and thus not be immutable, simple, and timeless. ${ }^{25}$ On four-dimensional eternalism this is not the case. Moments of time do not slough off into the nonexistent past and there are no yetto-exist future moments. All of time exists and is sustained by God in one timeless immutable act. God, it is argued, can exist all at once instead of having to lose moments of His life as He would on presentism.

The third and final purported theological benefit that I will mention is related to the problem for divine timelessness from omniscience. Again, Classical theologians held presentism and divine timelessness. They also made the claim that our present syncs up with, or is contained in, God's eternal present. ${ }^{26}$ As the Protestant scholastic Francis Turretin explains, "the past, while it was, coexisted in eternity, the present now coexists with it, and the future will coexist with it." ${ }^{27}$ A common theological prolegomena during

1983), 29-32; J. R. Lucas, A Treatise on Time and Space (London: Methuen, 1973), chap. 4; Boethius, Trinity Is One God Not Three Gods, 4; Thomas Aquinas, Quaestiones Disputatae De Veritate, q.2.12.

23. Paul Helm, Eternal God: A Study of God without Time, 2nd ed. (New York: Oxford University Press, 2010), chap. 14. Also, Helm, "Divine Timeless Eternity," in God \& Time: Four Views, ed. Gregory E. Ganssle (Downers Grove, IL: InterVarsity, 2001), 47-51. Katherin Rogers, "Anselm on Eternity as the Fifth Dimension," The Saint Anselm Journal 32 (2006): 3.

24. See my "Divine Perfection and Creation," The Heythrop Journal.

25. Rogers, "Back to Eternalism," 331.

26. Rory Fox, Time and Eternity in Mid-Thirteenth-Century Thought (Oxford: Oxford University Press, 2006), 89-91.

27. Francis Turretin, Institutes of Elenctic Theology, 3.11.8-9. 
the Middle Ages, Reformation, and today surrounds God's knowledge of the present. For thinkers like Augustine and Peter Lombard, the question was this: does God's knowledge grow when He creates the world? It would seem as if there is something new for God to know once the word comes into existence. God would go from knowing that $<$ The universe does not exist $>$ to knowing that $<$ The universe does exist $>{ }^{28}$ For Aquinas, the question was a bit different. Does God have knowledge of temporal concrete particulars? Creatures have knowledge of temporal concrete particulars. God is a perfect knower, so He should know everything creatures do and more. ${ }^{29}$ This issue is closely related to the question that is discussed at length in contemporary debates. In contemporary debates the question is this: does God know what time it is now? $?^{30}$ If God knows what time it is now, His knowledge will constantly be changing since "now" will continually pick out different moments as time moves forward. As such, God cannot be timeless. If God does not know what time it is now, He is not omniscient.

By adopting four-dimensional eternalism one avoids the problems of God's knowledge growing as the world unfolds through time. Strictly speaking, there is no unfolding through time. From God's perspective, the best perspective, the whole four-dimensional universe simply exists. There is no knowledge for God to gain. Can God know what time it is now? No, because there is no now with a unique ontological status. Granted, from the perspective of temporal creatures things appear as if the present is unique and that the past no longer exists and the future does not yet exist. This, however, is not the way reality is. Terms like "past," "present," and "future" are relative from the perspective of temporal parts or person stages. From God's perspective, the best perspective, He sees the world as it actually is. From His perspective there is no "now," there is just the entire fourdimensional spacetime world. $^{31}$

Ultimately, I do not think that four-dimensional eternalism saves divine timelessness since the Christian God is still related to a changing, temporal

28. Augustine, City of God, 11.21; The Trinity 6.11 and 15.22; On Genesis, 5.6. Peter Lombard, Sentences, Book 1, Dist. 35.9.1-2; and Dist. 34. Cf. John Philoponus, Against Proclus on the Eternity of the World 12-18, trans. James Wilberding (London: Duckworth, 2006),74-81.

29. Aquinas, Quaestiones Disputatae De Veritate, q.2.1-14; Summa Contra Gentiles, 1.657.

30. William Lane Craig, "Divine Eternity," in The Oxford Handbook of Philosophical Theology, ed. Thomas P Flint and Michael C. Rea (New York: Oxford University Press, 2009), 159-60. Nicholas Wolterstorff, Inquiring about God: Selected Essays (New York: Cambridge University Press, 2010 ), 150-2. Interestingly, divine temporalists from the seventeenth and eighteenth century, like Samuel Clarke, Pierre Gassendi, and Thomas Hobbes, did not offer this objection. They seem to agree with Augustine's solution to the problem - a perfect being does not know what exists now because a perfect being would not be perfect if its knowledge depended upon the changing temporal world.

31. Rogers, Perfect Being Theology (Edinburgh: Edinburgh University Press, 2000), 604. "Anselm on Eternity as the Fifth Dimension," 2-7; The Anselmian Approach to God and Creation (Lewiston: Edwin Mellen, 1997), 209-12. 
world and even becomes incarnate and thus exists at particular times and possesses temporal parts. The eternalist world is not an unchanging, timeless world. However, I will set that aside for this paper. In the remainder of this paper I will focus my critique on four-dimensional eternalism since it is said by its proponents to salvage divine timelessness, and for various Christians that is a significant theological benefit, though, for theologians such as myself, this is not a benefit. I take it that my arguments below could be slightly modified to work against the growing block view as well, but will not focus on the growing block since it does not offer the same advantages for divine timelessness that eternalism is said to bring. I shall argue that fourdimensional eternalism exaggerates the problem of evil and wreaks havoc on Christian eschatological hope and practice. As such, Christians who hold to, or are tempted to hold to, four-dimensional eternalism should reconsider their ontology of time and their theory of persistence through time.

\section{Four-Dimensional Eternalism, Evil, and Christian Belief}

A brief note is in order on personal persistence through time and anthropology. There are many views within philosophical anthropology such as dualism, physicalism, and material constitution. ${ }^{32} \mathrm{I}$ am an unrepentant substance dualist, presentist, and endurantist. I hold that a person is an immaterial mind. Human persons are minds embodied in human organisms. A person persists through time by existing as a whole, or all at once. The numerically same mind who suffers in this life, will be the numerically same mind who shall receive eschatological healing. I also hold that our personal survival of death matters deeply to us. I want to be the numerically same person who receives eschatological healing.

Most four-dimensionalists reject substance dualism and opt for some form of physicalism, though it is possible to be a substance dualist. ${ }^{33} \mathrm{On}$ four-dimensionalism personal persistence is typically understood in terms of psychological continuity since it explicitly denies numerical identity over time. The person stage that exists at time $t_{1}$ persists by having a temporal counterpart at some later time $t_{2}$. This later temporal counterpart will exemplify a psychological continuity to the earlier temporal counterpart in that each will have the same beliefs, memories, desires, and so on. ${ }^{34}$ Four-

32. Eric T. Olson, What Are We? A Study in Personal Ontology (New York: Oxford University Press, 2007).

33. Hawley lists dualism as a possibility throughout How Things Persist. For a materialist account of personal persistence on four-dimensionalism see Hud Hudson, A Materialist Metaphysics of the Human Person (Ithaca, NY: Cornell University, 2001).

34. Tobias Hansson Wahlberg, "Can I Be an Instantaneous Stage and Yet Persist Through Time?," Metaphysica 9 (2008): xxx-xxx. 
dimensionalists also typically hold that personal survival of death does not really matter to us. As Eric Steinhart proclaims, "Personal identity is not retained in the resurrection. It is sacrificed." ${ }^{35}$ According to Steinhart, and others, what really matters to us is that we have later resurrected temporal counterparts. Apparently, human persons do not really concern themselves with personal survival, but only care about having later temporal counterparts. I should think that this will be quite shocking news to most human persons to hear that personal survival is not what matters to them, but I digress.

It is at this point that I think one can begin to see the failure of fourdimensionalism for Christianity. On standard Christian defenses and theodicies the problem of evil is in part assuaged by the promise of personal eschatological healing, resurrected bodies, reconciliation with other persons (both human and divine), and an eternal and blissful union with God. The Christian claim is that God would not create a world where evil has the ultimate say, nor would He create a world where there is a perfect balance of good and evil. The Christian God is an evil defeater, not an evil balancer. God will bring about a state of affairs where goodness will outweigh any past evils. ${ }^{36}$ One way to capture this is to say that God will ensure that human persons who participate in horrors will have their horrors defeated. God will ensure that these human persons will have a life that, on the whole, is one worth living. One day their suffering will cease, and they shall receive resurrected bodies and enter into God's everlasting kingdom. ${ }^{37}$ A presentist has no problem making sense of these claims since past horrors no longer exist. The numerically same endurant person who participated in horrors will be the numerically same person who will be resurrected in the future. Those tragic moments of her past no longer exist, and she has an eternity of future healing and bliss to look forward to. I shall argue that a four-dimensional eternalist cannot make good on these claims. In particular, a four-dimensional eternalist cannot make good on the claim that the participant of horrors will cease to participate in those horrors, nor that God will ultimately defeat evil.

\section{A. The Initial Exaggeration of the Problem of Evil}

On four-dimensional eternalism persons persist by having temporal parts, or stages, that are psychologically continuous with earlier temporal

35. Eric Steinhart, “The Revision Theory of Resurrection,” Religious Studies 44 (2008): $66-7$.

36. Klaas J. Kraay, "Theism, Possible Worlds, and the Multiverse," Philosophical Studies 147 (2010): xxx-xxx; Keith Yandell, "Theology, Philosphy, and Evil," in For Faith and Clarity: Philosophical Contributions to Christian Theology, ed. James K. Beilby (Grand Rapids, MI: Baker Academic, 2006); John S. Feinberg, The Many Faces of Evil (Wheaton: Crossway Books, 2004).

37. Marilyn McCord Adams, Christ and Horrors: The Coherence of Christology (Cambridge: Cambridge University Press, 2006). 
parts. On four-dimensional eternalism the entire spacetime manifold exists and contains all events. The temporal parts of each object exist only at the times at which they exist. From God's perspective, it simply is the case that each temporal part exists at the times at which they do from all eternity. It is always the case that a temporal part of $\mathrm{O}$ exists at time $\mathrm{t}_{\mathrm{x}}$. Further, the entire four-dimensional universe is coeternal with God in the sense that there is never a state of affairs where God exists without the universe.

Imagine if you will that Sally is enjoying an absolutely delectable cheeseburger. Perhaps it is the best cheeseburger in town. On four-dimensional eternalism it is always the case that there is a temporal counterpart, or person stage if you prefer, of Sally enjoying this delectable cheeseburger. From all eternity this temporal counterpart of Sally is enjoying this cheeseburger. Not a bad situation to be in if you ask me.

Imagine a different scenario. There is another temporal counterpart, or person stage, of Sally that is experiencing an absolutely tragic evil. From all eternity that temporal counterpart of Sally is suffering this great evil. This temporal counterpart will never cease to suffer. Granted, other temporal counterparts of Sally are enjoying delectable cheeseburgers, or perhaps even enjoying the beatific vision. This would appear to offer no consolation to the temporal counterpart that is suffering. Her suffering will never cease. From all eternity God is sustaining this temporal counterpart in existence. This temporal counterpart of Sally is suffering an eternal torment with no chance of relief. This temporal counterpart will never be able to say, "Thank goodness that is over." This is a hard picture of reality to maintain. This seems to exaggerate the problem of evil for the Christian since it cannot make good on the claims that the suffering will cease, and that evil will ultimately be defeated.

It should be noted that the intensity of Sally's suffering is not somehow greater on four-dimensionalism than it would be on presentism. The level of intensity is the same on either account ${ }^{38}$ A stubbed toe is a stubbed toe on four-dimensional eternalism and presentism. The difference is that on presentism and endurantism Sally will eventually cease to suffer, whereas on four-dimensional eternalism the person stage that exists at the time of the suffering will never cease to exist at the time of the suffering. Granted, Sally has later temporal counterparts that are not suffering, but that does not relieve the suffering of the earlier Sally stage. The suffering person stage is coeternal with God. It is difficult to see how God could be an evil defeater on four-dimensional eternalism. 


\section{B. A Possible Rejoinder}

A four-dimensional eternalist might offer a possible rejoinder by saying that the future is longer than the past. All of the bad stuff in the past remains, but perhaps there are more temporal counterparts of Sally that are enjoying great moments of bliss and joy such that, overall, the balance outweighs the evil. ${ }^{39}$ Say that later temporal counterparts of Sally are enjoying the beatific vision, joyous fellowship within the communion of the saints, and so on forever and ever amen. Overall, Sally's life is good such that it outweighs the evil experiences in her life. If this is the case, perhaps one could still maintain that God is an evil defeater whilst conceding that the earlier temporal counterparts continue to suffer.

\section{At Best, God Is an Evil Balancer, Not an Evil Defeater}

What must be understood is that on four-dimensional eternalism we have a massive number of person stages that are experiencing evil. It is not obvious that the number of person stages that are experiencing great bliss outweighs the number of person stages that are experiencing great suffering. Stages have the same structure as instants. They are as fine-grained as time and possible change. ${ }^{40}$ On worm theory Sally has a temporal counterpart at every instant at which she exists. On stage theory there is a person stage "Sally" at every instant.

If time is dense and/or continuous there is an instant between any two instants. In other words, time is infinitely divisible. This means that the number of temporal counterparts and person stages is infinitely divisible. What we have are an infinite number of person stages suffering great evil and an infinite number of person stages enjoying great bliss. On this scenario it is not the case that Sally's life is overall good. There is a perfect balance of good and evil, but Christian theology is committed to the claim that the good will outweigh evil. God is not an evil balancer, He is an evil defeater. Fourdimensional eternalism cannot make good on this claim.

One could escape this by holding that time is discrete and not infinitely divisible. On this scenario there could be more person stages enjoying bliss than those suffering. Perhaps the four-dimensionalist could argue that on this scenario the good does outweigh the evil. Yet, this will not offer a completely satisfactory solution since Christian theology is not merely committed to the

39. Thanks to Katherin Rogers for offering this rejoinder to me.

40. Katherine Hawley, How Things Persist, 48-52. 
claim that good will ultimately outweigh evil. As discussed further in the next section, Christian theology is also committed to the claim that evil will cease to exist, and that the suffering of the redeemed will come to an end. On this scenario we still have a massive number of temporal parts suffering a torment from which they will never find relief.

A four-dimensionalist might try to assuage the problem by saying that stages cannot be persons. However, they look enough like persons to make the objection go through for each temporal part of a person is a conscious thinking thing with free will. In explaining the concept of temporal parts and the rejection of a privileged present on four-dimensional eternalism, Katherin Rogers explains that a perdurant person is made up of an infinite number of temporal parts. Each temporal part believes that she exists at the present. " $[T]$ he 'I' of an instant ago really exists and perceives an instant ago as the present instant, and the 'I' of an instant hence really exists and perceives an instant hence as the present instant. And these successive timeslices of 'me' do not have access to one another." clearly conscious things. The stage theorist will openly admit this as well because she is committed to person stages. ${ }^{42}$

However, not all worm theorists will agree. A worm theorist might continue to say that temporal parts are not persons. One argument in favor of the view that temporal parts are not persons is that temporal parts are too brief to be things that could think and act. If the worm theorist offers this argument she must explain how a spacetime worm could be a person. The worm is a sum of temporal parts that are essentially nonthinking things.

A problem for the four-dimensionalist would arise at this point. How could something composed of essentially nonthinking things be a thinking a thing? As noted above, the standard account of perdurance holds to a supervenience relation between the sum and its parts. If the parts are not thinking things, the sum will not be a thinking thing. The four-dimensionalist says that personal persistence occurs through psychological continuity, but we seem to not have anything here with a psychology. We do not seem to have any persons. This allows the four-dimensionalist to say that there are not an infinite number of persons suffering, but it does so at the cost of eliminating persons from the world. I doubt most Christian four-dimensionalists will want to take this route.

The best way around this is to say that each temporal part of a person is a thinking thing. Recall from above that four-dimensionalists are typically committed to metaphysical universalism. There are an infinite number of ways a perdurantist could cut up a spacetime worm. Perhaps the perdurantist will grant that stages are far too brief to be persons. She can cut her temporal parts thicker than stages such that they are not too brief to be persons. Instead

41. Rogers, "Anselmian Eternalism," 7.

42. Hawley, How Things Persist, 64-7. 
of having person stages, she will have person segments that are comprised of various stages ${ }^{43}$ However, this will not help assuage the problem of evil for we are right back where we began. If spacetime worms can be cut up an infinite number of ways into an infinite number of person segments, we have an infinite number of suffering temporal parts.

So where does this leave us? Perhaps the four-dimensionalist can modify the above rejoinder such that it gives her a prima facie defeat of evil wherein the good does outweigh the evil. She can say that time is discrete, and deny person segments. Instead, there are a discrete number of person stages in the world, and these person stages really do count as persons. The number of person stages enjoying great bliss outweighs the number of person stages suffering horrors. This would seem to assuage the problem noted above somewhat.

I maintain, however, that this does not offer an ultimate defeat of evil. At best, it gives us a God who is an evil balancer, and not an evil defeater. I concede that, on four-dimensionalism, other temporal counterparts of Sally are enjoying the great things of the eschaton, but this does little to assuage the eternal suffering of the earlier temporal counterparts of Sally. From the perspective of the suffering temporal counterparts there is no relief. Even from God's eternal perspective these temporal counterparts have no relief for $\mathrm{He}$ is eternally sustaining them in existence. Again, these suffering temporal counterparts are coeternal with God. This is not an ultimate defeat of evil.

\section{Where Is the Evil Defeater?}

Christians are committed to the claim that one day God will ultimately triumph over evil and renew creation (for example, Rev. 20-22). It is hard to understand how, on this model, God can be said ultimately to triumph over evil and renew creation. "Creation is never really purged of evil on this view; at most it can be said that evil infects only those parts of creation that are earlier than" other events like Christ's return and the general resurrection of the dead. ${ }^{44}$ It is difficult to understand how there will be no more tears when Christ comes again if other temporal parts of the saints are eternally experiencing great evil. The temporal parts of the martyrs from Nero's day are - tenselessly — serving as torches for his parties. Granted, other temporal parts of the martyrs are enjoying the new creation, but the flames of the previous temporal parts will never be extinguished.

43. Cf. A. P. Taylor, "The Frustrating Problem for Four-Dimensionalism," Philosophical Studies (forthcoming).

44. William Lane Craig, "Response to Paul Helm," in God \& Time: Four Views, ed. Gregory Ganssle, 66. See also Keith Ward, "The Temporality of God," International Journal for Philosophy of Religion 50 (2001): 162. 
Several things are needed for God to defeat the horrors of these martyrs. First, God must make it the case that their suffering comes to an end. Second, God must take them out of the environment where they are vulnerable to horrors. Third, God must heal them. ${ }^{45}$ Four-dimensional eternalism cannot make good on these claims. The suffering temporal parts eternally suffer. Their suffering cannot come to an end, nor can they be taken out of the environment in which they are vulnerable to horrors. This is because their temporal and spatial locations are eternally fixed. Their temporal and spatial locations are coeternal with God. As such, these temporal parts will never be healed. Later temporal counterparts will be enjoying God's healing, but not the counterparts that are eternally suffering. It is awkward, to say the least, that the suffering counterparts do not receive any healing, but that the counterparts that never have and never will suffer do receive the healing. ${ }^{46}$ This seriously calls into question the claim that God is an evil defeater.

There is another awkward tension between Christian theology and fourdimensionalism. On four-dimensional eternalism evil is coeternal with God. There is no state of affairs where God exists and evil does not. From the perspective of God, the best perspective, evil eternally exists. One might be tempted to say that this is some form of dualistic heresy where good and evil are coeternal - perhaps something in the vein of Gnosticism or Manichaeism. That is not quite right. On four-dimensional eternalism evil is coeternal with God, but unlike God it is contingent. Evil is not on a par with God. However, this does not make things much better for one still has to reconcile the goodness of God with a coeternal evil that cannot be eradicated. The evil that men suffer at particular times will never be defeated. It remains eternally. Where, then, is God the evil defeater?

\section{The Eschatological Woes of Four-Dimensionalism}

Eschatology becomes increasingly bizarre if four-dimensional eternalism is true. ${ }^{47}$ Eschatology has several themes, one of which is the already/not yet tension in the New Testament. ${ }^{48}$ The central idea is that Jesus has begun the kingdom of God, or begun the "age to come", such that in a sense we can say things like "I am saved" or "the kingdom of God is here."

45. This is a modification of Adams's stages of horror defeat in Christ and Horrors.

46. Steinhart's theory of the resurrection is quite explicit that only the resurrected counterparts receive healing whilst the suffering counterparts do not. See his, "Revision Theory of the Resurrection."

47. For an interesting discussion on four-dimensionalism and Catholic eschatology see Patrick Toner, "Divine Judgment and the Nature of Time," Faith and Philosophy 22 (2005): xxx-xxx. Also Alexander Pruss, "Toner on Judgment and Eternalism," Faith and Philosophy 25 (2008): $\mathrm{xxx}-\mathrm{xxx}$.

48. For more on the already/not yet see Craig C. Hill, In God's Time: The Bible and the Future (Grand Rapids, MI: Eerdmans, 2002). 
However, the kingdom has not yet been fully realized, or fully consummated. This is why we can say things like "I am being saved," "I will be saved," or "God, please bring about your kingdom." The apostle Paul often speaks of the present experience of salvation and God's kingdom, but at the same time looks forward to the reappearing of Christ and His coming kingdom in which the general resurrection of the dead will take place and salvation will be complete. ${ }^{49}$

In light of this theologians often emphasize that living in this already/ not yet creates a prolepsis, or anticipation, toward God. ${ }^{50}$ Because of the in-breaking kingdom of God as displayed through the work of Christ we have certain promises from God about the future. These promises are about the general resurrection of the dead, the reconciliation of all things to God, the new creation, and the end of death and evil. Since we can currently experience these things to a limited degree through the work of the Holy Spirit, the life of Christ and the promises of God through Christ should call us to reorient the way we live our lives. Part of the idea of "prolepsis" is to reorient our lives according to what God has done in the past, is doing in the present, and will do in the future when Christ reappears. The presentist and endurantist has no problem making sense of these claims, but the fourdimensional eternalist does.

If presentism and endurantism are true, human persons who currently exist can experience the proleptic work of the Holy Spirit in their lives. Since the future does not yet exist, a person can have hope for future resurrection. She can orient her life around the promises of God through Christ that have not yet been fulfilled. The numerically same person who orients her life around God's eschatological promises will be the numerically same person who will one day experience the fulfillment of those promises. When that day comes, and since the past no longer exists, she can finally have a sigh of relief that evil is no more.

If four-dimensional eternalism is true, I shall argue that these ideas within eschatology become perplexing to say the least. A number of questions arise at this point for the four-dimensional eternalist. How far should we proleptically reorient our lives given that Christ's reappearing is occurring at a particular time that tenselessly exists? Should we be concerned with the afterlife? Should we look forward to the new creation? Should we be concerned with hell? I shall take each question in turn.

49. Ben Witherington III, The Paul Quest: The Renewed Search for the Jew of Tarsus (Downers Grove, IL: InterVarsity, 1998), chap. 8.

50. Richard Bauckham, "Eschatology," in The Oxford Handbook of Systematic Theology, ed. John Webster, Kathryn Tanner, and Ian Torrance (New York: Oxford University Press, 2007), 308-11. 


\section{A. Should We Proleptically Reorient Our Lives Toward the Reappearing of Christ?}

One's own proleptic anticipation of Christ's future reappearing would seem rather odd on four-dimensional eternalism. Let us say that Christ comes again in the year 3000. For those of us who are temporal parts, or person stages, living at the time 2014, it seems like we can look forward to Christ's reappearing. However, it simply is the case that Christ is tenselessly reappearing at the year 3000. This is because both times and the temporal parts that exist at those times have equal ontological existence. This creates several problems.

In Romans 8:18-25, Paul writes,

For I consider that the sufferings of this present time are not worth comparing with the glory that is to be revealed to us. For the creation waits with eager longing for the revealing of the sons of God. For the creation was subjected to futility, not willingly, but because of him who subjected it, in hope that the creation itself will be set free from its bondage to corruption and obtain the freedom of the glory of the children of God. For we know that the whole creation has been groaning together in the pains of childbirth until now. And not only the creation, but we ourselves, who have the firstfruits of the Spirit, groan inwardly as we wait eagerly for adoption as sons, the redemption of our bodies. For in this hope we were saved. Now hope that is seen is not hope. For who hopes for what he sees? But if we hope for what we do not see, we wait for it with patience.

In this passage creation and humanity are eagerly awaiting the future redemption of all things. When Christ reappears He will bring about the resurrection of our bodies, and renew all of creation. Paul tells the Romans that they have hope for this future event. They have hope, because this event has not yet obtained - they haven't yet seen it or experienced it. If they had experienced it—if the event had obtained — they would have no hope. For no one continues to place her hope in something once that thing has obtained. If I have high hopes about eating a delectable cheeseburger, my hope comes to an end once I take my first bite of that cheeseburger. My hope gives way to the enjoyment, or disappointment, of what I had hoped for.

It would seem that, on four-dimensional eternalism, the groaning of creation in anticipation of the coming kingdom is futile. The kingdom has come at a particular time slice. Those who exist at earlier time slices who yearn for the coming kingdom will never experience the kingdom of God because they eternally exist at the times at which they do in fact exist. Whence then is their hope? These temporal counterparts have placed their hope in a future event that is eternally inaccessible to them. Perhaps one can say that these temporal counterparts do have genuine hope since the object 
of their hope is an event that is later than the time slice at which they exist. It is the case that they hope for what they do not see, but it would sound like a cruel joke to tell them to "wait for it with patience" since no amount of patience will ever bring this event closer to them. Those patient temporal counterparts will never experience the eschatological glory and redemption that Paul speaks of. They may have genuine hope, but it seems that fourdimensional eternalism renders their hope futile. Their proleptic anticipation is in vain.

A related question is worth asking as well. What is Sally actually doing when she participates in the Lord's Supper? Supposedly she is celebrating Christ's death until He comes again (1 Cor. 11:26). However, on fourdimensional eternalism, Christ has come. Granted, He has not subjectively come from the perspective of those existing at earlier times, but objectively the event is actual.

Part of the idea of prolepsis is an excited, or celebratory, anticipation toward the future fulfillment of God's promises. When one comes to participate in the Eucharist she is celebrating what God has done in the past, what $\mathrm{He}$ is currently doing, and what He will do in the future. She celebrates Christ's life and His future return when all things will be put right. The body of Christ, the Church, is meant to come together to celebrate such things in the Lord's Supper, and as a body proleptically orient themselves toward this future return of Christ.

Yet it seems that four-dimensional eternalism cuts against the very idea of proleptic anticipation and celebration of the Lord's Supper. Consider Sally again. The Sally person stage that is participating in the Lord's Supper has little to celebrate for she will never experience the resurrected Lord. The stage that celebrates the Lord's Supper until Christ returns is celebrating something that is eternally inaccessible to her. What then is she celebrating? Perhaps she can celebrate the fact that her later temporal counterparts are enjoying the return of Christ, but it seems to me that it will be difficult to get into a celebratory mood over such things. It is hard to get excited about a party that you cannot possibly attend. How much more so, then, will it be difficult to get excited about the return of Christ when you know that you cannot possibly experience it? This has the potential to turn the celebration of the Lord's Supper into the mourning of a wake. At best, it has the potential to turn the body of Christ into a bunch of party poopers who come to take the bread and wine, but can only complain about the fact that they will never see the return of their Lord. Four-dimensional eternalism seems to wreak havoc on Christian hope and practice. 


\section{B. Should We Be Concerned with the Afterlife?}

Let us consider Sally again. Given four-dimensional eternalism there are Sally person stages that exist in the year 2014. Person stages are as finegrained as instants and possible change. The number of person stages that exist in 2014 depends on whether time is continuous or discrete. Either way, there are a large number of Sally person stages that exist in 2014. It is the case that certain later temporal counterparts of Sally exist in either hell or the new earth. However, the Sally stage that exists at this time will never experience such things. The Sally stage that exists at this time will only exist at this time. She will never have the beatific vision or experience the torments of hell.

Consider first the new creation. Does Sally have anything to look forward to in regards to the new creation? The Sally that exists at this time has nothing to look forward to. She cannot possibly experience the joy of being reunited with loved ones in the new creation. She will never experience the eschatological healing of her body because a later temporal counterpart will be the one resurrected. No beatific vision awaits her for she eternally exists at the wrong time to experience such things. In moments of hardship, she might be tempted to take solace in the fact that one day she will fully experience the love and forgiveness of God. But upon reflecting on her ontological status within time, she will most likely lose whatever comfort such thoughts were intended to bring for she will eternally exist at that moment of hardship.

Perhaps things will not be so dire for certain Sally stages. Say there is a Sally stage that is not experiencing a moment of hardship, nor suffering a horrendous event. Say instead, there is a particular Sally stage that is experiencing a rather tantalizing sin. Should she be worried about the eternal consequences of this $\sin$ ? Should she be worried about the eternal destiny of her soul? It seems she should not. She already knows that she will never experience new creation, but she can take solace in the fact that she has no worry of hell either. The stage that exists at this time will never have to experience hell. She eternally exists at the moment of enjoying this tantalizing sin. No need to worry about eternal consequences, for she will never have to experience them. For all eternity she will experience the pleasure of this tantalizing sin.

Perhaps the four-dimensionalist could argue that this particular Sally stage has a duty to seek the kingdom of God so that later temporal counterparts can enjoy the beatific vision and not experience the torments of hell. As such, this Sally stage should not take solace in the fact that she cannot possibly experience hell. Instead she should be concerned about the eternal destiny of her later temporal counterparts. ${ }^{51}$ But surely her moral

51. See Taylor for an argument that four-dimensionalism is not compatible with satisfying obligations to persons with regard to the person's well-being. Taylor, "The Frustrating Problem for Four-Dimensionalism." 
motivation is significantly undercut in the same way that her hope about the future is undercut. It eternally is the case that Sally's temporal counterparts exist at the times and places that they in fact exist. The destiny of Sally's temporal counterparts is eternally fixed for those times eternally obtain.

\section{Concluding Remarks}

I have argued that four-dimensionalism exaggerates the problem of evil for Christian theism, and that it eradicates the proleptic hope of the believer as well as wreaks havoc on eschatology. My suggestion is that Christian philosophers and theologians should reconsider their commitment to fourdimensional eternalism in light of these arguments. Ultimately, I would suggest that Christians should abandon four-dimensional eternalism and return to the loving arms of presentism. Presentism served the Church well for over 1,800 years, and I say it could continue to do so again. ${ }^{52}$ Granted, presentism is not compatible with divine timelessness as noted above. So presentism and endurantism cannot deliver the alleged theological benefits of maintaining divine timelessness. But I doubt that divine timelessness is worth maintaining anyway. ${ }^{53}$ Instead, I posit that Christians should embrace presentism and endurantism, and suffer or enjoy, the theological consequences that follow. ${ }^{54}$

52. John Bigelow, "Presentism and Properties," Nous 30 (1996): 35. See also Dean Zimmerman, "The A-Theory of Time, Presentism, and Open Theism," in Science and Religion in Dialogue, ed. Melville Y. Stewart (Malden: Blackwell, 2010), 793.

53. For arguments against divine timelessness see my In Search of a Timeless God (forthcoming).

54. I would like to thank Oliver Crisp, Katherine Hawley, Chantal Incandela, Kate Rogers, Alan Torrance, Keith Yandell, and the editors and reviewers of Philosophia Christi for helpful comments on earlier drafts of this paper. 